Short Paper

\title{
Determinants of watermelon production and its impact on the farmers in Ifelodun L.G.A, Kwara State, Nigeria
}

\author{
Afolabi Monisola Tunde \\ Department of Geography \& Environmental Management, University of Ilorin, Nigeria. \\ Correspondence: folamoni70@yahoo.com; (ib https://orcid.org/ 0000-0003-3326-4064
}

Received: $8^{\text {th }}$ July 2019; Revised: $12^{\text {th }}$ November 2019; Accepted: $11^{\text {th }}$ December 2019

\begin{abstract}
This paper assesses the factors that encouraged watermelon production and their impact on the growers in a rural part of Ifelodun L.G.A, Kwara State, Nigeria. It further analyzes factors affecting the production and evaluates the determinants of rural farmers for diversification into watermelon production, impacts of growing watermelon on the livelihood of the producers and the constraints involved in its production. Purposive sampling technique was used and a total of one hundred and six (106) farmers involved in producing watermelon in the study area were selected. Focus group discussions (FGDs) were used to complement the questionnaire. The study employs Likert Rating Scale, descriptive and inferential statistics to analyze collected data. The results revealed that nature of soil and amount of water/ rainfall with a coefficient of determination of 0.779 and 0.859 respectively, are the most important factors affecting the production of watermelon. It was further discovered that accessibility to fertile land $(\mathrm{x}=3.9)$ and income generation $(\mathrm{x}=3.7)$ are the most important determinants for diversification into watermelon production by farmers. It revealed that watermelon production has significantly contributed to the income, health and livelihood of the people involved in it. Hence, the practice of horticulture should be encouraged more in other rural local governments of Kwara State for sustainable rural development. Proper institutional support towards the development and growth of watermelon should be put forward by policy makers.
\end{abstract}

Keywords: Horticulture, income generation, rural areas, watermelon.

\section{Introduction}

Agriculture is an indispensable sector in Nigeria despite its heavy reliance on oil. Studies have shown that $70 \%$ of Nigerians live in rural areas (Egbe 2014), and their primary occupation is farming. Majority of the farmers in the rural 
areas are small holders who depend largely on simple implements for crop production (Dan-Azumi 2011), and they grow different kinds of vegetables and fruits, including watermelon. The important roles played by fruits in the health and general well-being of man cannot be over emphasized. Fruits provide important vitamins to the human body while contributing significantly to the livelihood of farmers involved in producing fruits. Watermelon belongs to the family Cucurbitaceae, which includes cucumbers, muskmelons, squash, pumpkins and gourds (Schippers 2000). It occupies the third position among the world's highly cultivated crops, and China is known to be the current highest producer of watermelon worldwide (Dhaliwal 2017). The fruit thrives very well on fertile sandy soil particularly on sandy riverbanks and requires little maintenance once it sprouts. According to Zafour (2007), watermelons are grown both in the tropics and subtropics, although they do best in the hot drier areas with abundance of sunshine.

Consumers have realized that watermelon is not just a summer fruit due to its health benefits (Baxley 2018). For instance, Agricultural Marketing Resource Center (2018) reported that one cup of diced, fresh watermelon provides $21 \%$ of the daily requirement of vitamin C, $18 \%$ of vitamin A, significant levels of vitamin B6, lycopene, antioxidants and amino acids. In Nigeria as well as in other parts of the world, watermelon is highly relished as a fresh fruit preferably for thirst-quenching attribute in addition to the many other identified nutritional values. In a study by Oguntola (2006), among five other exotic vegetables examined in Ibadan city of Oyo State, Nigeria, watermelon was reported as the most preferred. It consisted of $93 \%$ water and little amounts of fat, protein, minerals and vitamins (Namdari et al. 2011). It is a major fruit in Ifelodun Local Government Area of Kwara State, Nigeria. Mohammed (2011) confirmed this by reporting that an average yield of 57.70 $\mathrm{kg} /$ hectare for sole melon was obtained on a field in Ifelodun Local Government Area Kwara State. The fruit and the seeds are used as a domestic remedy for urinary tract infection, control of blood pressure and possibly prevent stroke, and also can treat eye problems, dry skin, eczema, cancer, hepatic congestion, catarrh and psoriasis (Adekunle et al. 2007, Enukainure et al. 2010, Inuwa et al. 2011). Dauda et al. (2008) reported that despite all these nutritional benefits from watermelon, the production of the fruit is still low in Nigeria. It is against this background that some farmers are diversifying into watermelon production in some parts of the country. This study therefore assesses the factors that encouraged watermelon production and its impact on the growers in a rural part of Ifelodun L.G.A, Kwara State.

According to David Livingstone (a missionary explorer), watermelon originated in the Kalahari Desert and semi-tropical regions of Africa in the 1850s. Presently, watermelons are cultivated as an important source of water during dry periods in these areas. The Food and Agriculture Organization (2003) reported that watermelon is one of the most widely cultivated crops in the world with a global production of about 89.9 million metric tons. 
According to the National Agricultural Statistics Service, the United States cultivated 50,990.4 hectares of watermelons with a value of $\$ 460$ million in 2009. As a traditional food plant (Gyulai et al. 2011), watermelon can improve nutrition, supplement food security, promote rural development and support sustainable land cares (Peet 1995; National Research Council 2008). According to Mohammed (2011), seedless watermelon is grown by small holder rural farmers and usually inter-planted with crops like maize, yam, cassava, pepper to make maximum use of the land resources and increase returns from the production systems. It has an average temperature requirement of between $65^{\circ} \mathrm{F}$ and $95^{\circ} \mathrm{F}$ and requires a constant supply of moisture during the growing season. Ufoegbune et al. (2014) compared crop parameters between wet and dry season in Abeokuta, Nigeria, and has recommended that watermelon should be planted in dry season with application of irrigation and in the wet season with supplemental irrigation. Adekunle et al. (2007) noted that watermelon thrives well in the northern part of Nigeria where suitable drier savanna agro ecology is found, and hence, it is the highest producing area. Essentially, based on the benefits derived from watermelon, the fruit is currently grown on all continents throughout the warm regions of the globe including Kwara State, Nigeria.

Recently, it was discovered that a group of farmers migrated to Oro-ago and Ago-olomo communities to farm and specifically grow watermelon. The question now is what could be responsible for this action? It was against this development that the present study aimed to examine perception on the determinants of watermelon production and their impact on the growers in a rural Ifelodun L.G.A, Kwara State. Specifically, the study examines the demographic characteristics of the farmers growing watermelon, identifies factors affecting the production of watermelon, evaluates the determinants of rural farmers' diversification to watermelon production, determines the impact of growth of watermelon on the livelihood of the producers and assesses the constraints faced by farmers in watermelon production.

\section{Material and Methods}

\subsection{Study Area}

Ifelodun local government area (Figure 1) of Kwara State is the study area. It is the largest local government area in Kwara State and is located within latitudes 8024" 41 and $8025 " 44 \mathrm{~N}$ of the equator and between longitudes $04035 " 35$ and $4035 " 02 \mathrm{E}$ of the East of the Greenwich meridian. It has nine districts and had a population of 206,042 as at 2006 census (NPC, 2006) with an area of $3,435 \mathrm{~km}^{2}$. The annual rainfall ranges between 1000 and $1500 \mathrm{~mm}$. The maximum average temperature ranges between $300{ }^{\circ} \mathrm{C}$ and $350{ }^{\circ} \mathrm{C}$ and 
humidity ranges from 35 to $60 \%$ (Mohammed 2011). The major source of livelihood and occupation of the people in the area is farming. Farming is traditional in nature with emphasis on the cultivation of crops such as sorghum, cassava, yam, maize and melon (Mohammed 2008). Cultivation of watermelon growth is very recent in Ifelodun, Kwara State. Productivity differences over time and farming types can result from a variety of factors including variations in scale or level of production.

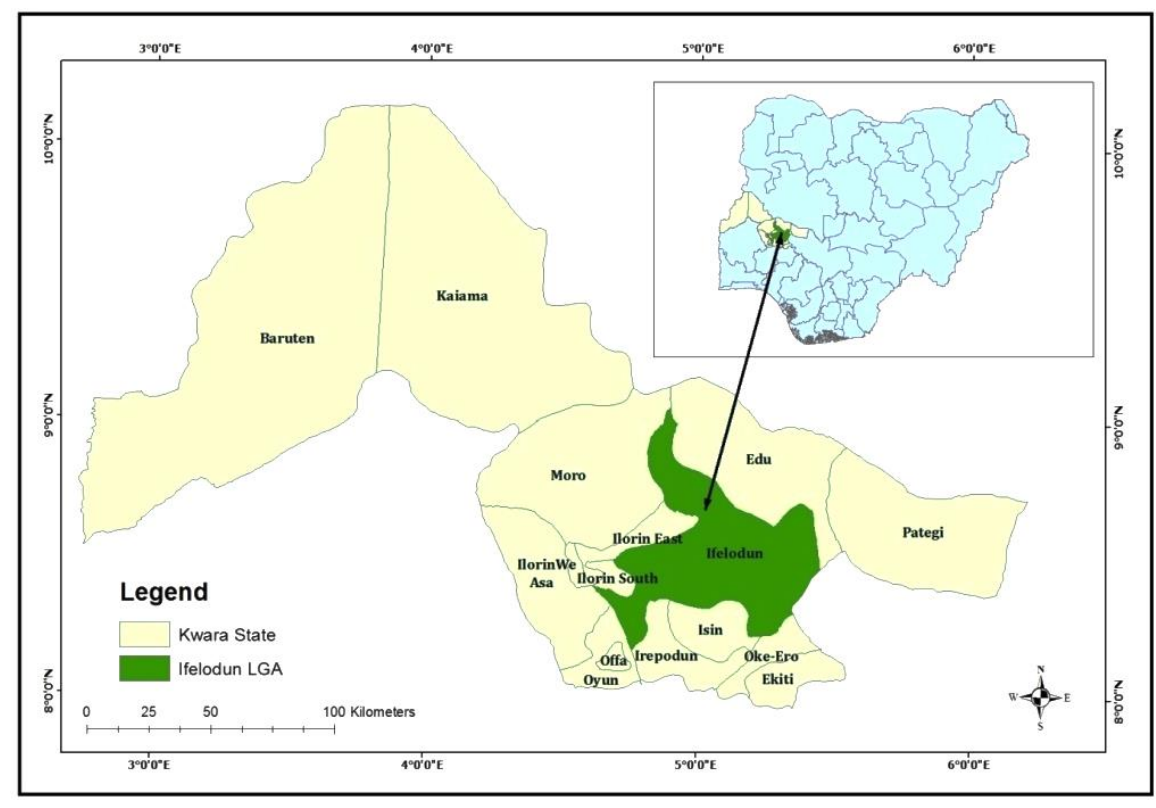

Fig. 1: Kwara State showing Ifelodun Local Government Area (Inset is Nigeria showing Kwara State) (Source: Kwara State Ministry of Lands, 2017)

\subsection{Methods}

A multistage sampling technique was employed in the study. The first stage involved purposive selection of the Local Government Area (Ifelodun) where watermelon is grown on commercial basis. The second stage was the purposive selection of the three villages in the local government area based on accessibility and the quantity of watermelon that are grown. Hence, all the one hundred and six (106) farmers involved in the production of watermelon in the study area were sampled by using copies of questionnaire. Focus group discussions (FGDs) were also organized for the farmers to complement the administered questionnaire. Simple parametric and non-parametric analyses were used to analyze the data gathered. To identify the factors affecting watermelon production, multiple regression analysis was employed. Likert 
rating scale and Matrix ranking were used to evaluate the determinants of rural farmers' diversification into watermelon production, the impact incomes generated from watermelon has on the livelihood of the farmers, and to assess the constraints facing farmers in watermelon farming respectively.

\section{Results and Discussion}

\subsection{Demographic characteristics of the farmers}

Majority of the farmers sampled were males. This is due to the traditional pattern that the male is dominant in the farming system in that area and because migrant farmers are mostly of male gender. Out of 106 farmers sampled, majority (95\%) were within the ages of 21-50 years, married and non-educated. The age signifies that most of the farmers are in the economically active age and therefore considered to be active and productive. This corroborates the findings of Yusuf et al. (2013) that most farmers are within the age bracket of less than thirty to fifty years. Most of them are married, meaning they have more mouths to feed and more hands to assist on farm. Average household size is 6; this could also mean an additional hand to help on farm. All of them are full-time farmers with over 5 years farming experience. Average annual income realized was $\$ 454,307.69$ in the study area. The finding agrees with Ebiwoei (2013) who reported that marketing of watermelon in the Niger Delta Area of Nigeria is highly profitable. Most of them (90\%) are migrant farmers who migrated from different parts of the country to embark on farming at various locations within Ifelodun local government area. This is as a result of the presence of fertile land for growing of the fruit.

\subsection{Factors affecting production of watermelon}

To determine perception of sampled farmers on the most significant factor affecting production of watermelon, seven variables were subjected to stepwise multiple regressions. The dependent variable is measured by the annual yield of watermelon. The independent variables are $X_{1}-X_{9}$.

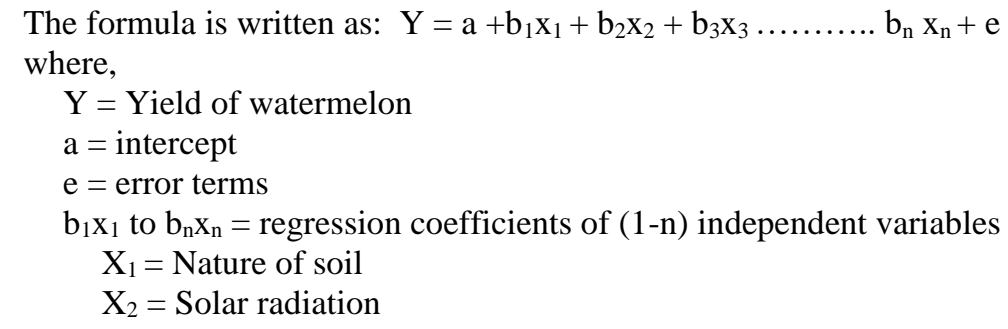


$\mathrm{X}_{3}=$ Amount of water/rainfall

$\mathrm{X}_{4}=$ Accessibility to fertile land

$\mathrm{X}_{5}=$ Availability of fertile land

$\mathrm{X}_{6}=$ Intensity of rainfall

$\mathrm{X}_{7}=$ Duration of rainfall

$\mathrm{X}_{8}=$ Number of rainy days

$\mathrm{X}_{9}=$ Type of seedling

These variables were chosen based on farmers' listing and reconnaissance survey carried out in the study area. The surrogate measure for each is percentage ranking by respondents in order of importance.

Table 1. Regression analysis on factors affecting watermelon production

\begin{tabular}{llcccc}
\hline Variables & $\mathrm{R}$ & $\mathrm{R}^{2}$ & $\begin{array}{c}\% \\
\text { Contribution }\end{array}$ & Adjusted R & $\begin{array}{c}\text { Std error of the } \\
\text { estimate }\end{array}$ \\
\hline Nature of soil $\left(\mathrm{X}_{1}\right)$ & 0.883 & 0.779 & 77.9 & 0.538 & 5.91 \\
$\begin{array}{l}\text { Amount of water/ } \\
\text { rainfall }\left(\mathrm{X}_{3}\right)\end{array}$ & 0.927 & 0.859 & 8 & 0.673 & 52.18 \\
\hline S & & & & & \\
\hline
\end{tabular}

Source: Researcher's Fieldwork/Computer Output, 2018

Table 1 shows the stepwise multiple regression analysis performed for factors affecting watermelon production in the study area. Out of the nine variables that were fed into the model, only two variables $X_{1}$ (nature of soil) and $X_{3}$ (amount of water/ rainfall) were found to be significant at the specified tolerance level of $5 \%$ for entry into the model. $X_{1}$ is the best predictor among the factors affecting watermelon production in the study area with a coefficient of determination of 0.779 . This indicates that $78 \%$ of the variance of nature of soil is associated with watermelon production in the study area. The implication of this is that watermelon thrives well in well-drained loamy soil which is peculiar to the study area. $\mathrm{X}_{3}$ (amount of water/ rainfall) appeared to be the next most important factor that determines the growth of watermelon. It has a coefficient of determination of 0.859 , meaning about $9 \%$ additional explanation of its variance is associated with variation in watermelon production in the study area. This means that amount of water required for the growth of watermelon should be regulated as this determines how well watermelon grows. It suggests that $85 \%$ of the joint variance in watermelon production is explained by variables $\mathrm{X}_{1}$ and $\mathrm{X}_{3}$. This is in accordance with the study by Adojutelegan et al. (2015) that rainfall, transportation, storage of watermelon, market price of watermelon and prevalence of pest and watermelon diseases were the factors that affect production of watermelon in Ekiti State, Nigeria. The remaining seven variables $\mathrm{X}_{2}, \mathrm{X}_{4}, \mathrm{X}_{5}, \mathrm{X}_{6}, \mathrm{X}_{7}, \mathrm{X}_{8}$ and $\mathrm{X}_{9}$ were not meaningful in explaining their variation because their correlation coefficients are too low. To complement the information obtained through the questionnaire, two sessions 
of focus group discussions (FGDs) were conducted to explore the opinion of the farmers on their level of understanding of factors affecting production of watermelon in the study area. According to them, the type of soil found in the study area is a significant factor that assisted the yield of watermelon. They considered all other factors to be secondary.

\subsection{Determinants of rural farmers' diversification into watermelon production}

To determine the factors responsible for rural farmers' involvement in watermelon production, the use of Likert rating scale was employed. Table 2 reveals the factors necessitating farmers' diversification to watermelon production.

Table 2. Determinants of rural farmers' involvement in watermelon production (\% within parentheses).

\begin{tabular}{|c|c|c|c|c|c|c|c|}
\hline $\begin{array}{l}\text { Determinants/ } \\
\text { Reasons }\end{array}$ & $\begin{array}{l}\text { Strongly } \\
\text { Agree }\end{array}$ & Agree & Disagree & $\begin{array}{l}\text { Strongly } \\
\text { Disagree }\end{array}$ & Undecided & $\begin{array}{l}\text { Weighted } \\
\text { Mean (X) }\end{array}$ & Rank \\
\hline Income generated & $\begin{array}{l}91 \\
(85.8)\end{array}$ & $\begin{array}{l}9 \\
(8.5)\end{array}$ & $\begin{array}{l}1 \\
(0.9)\end{array}$ & 0 & $\begin{array}{l}5 \\
(4.8)\end{array}$ & 3.7 & 2 \\
\hline $\begin{array}{l}\text { Nutritional benefits / } \\
\text { food security }\end{array}$ & $\begin{array}{l}61 \\
(57.5)\end{array}$ & $\begin{array}{l}20 \\
(18.9)\end{array}$ & $\begin{array}{l}10 \\
(9.4)\end{array}$ & $\begin{array}{l}2 \\
(1.9)\end{array}$ & $\begin{array}{l}13 \\
(12.3)\end{array}$ & 3.1 & 5 \\
\hline Unemployment & $\begin{array}{l}66 \\
(62.3)\end{array}$ & $\begin{array}{l}10 \\
(9.4)\end{array}$ & $\begin{array}{l}20 \\
(18.9)\end{array}$ & $\begin{array}{l}10 \\
(9.4)\end{array}$ & 0 & 3.2 & 4 \\
\hline $\begin{array}{l}\text { Accessibility to } \\
\text { fertile land }\end{array}$ & $\begin{array}{l}96 \\
(90.6)\end{array}$ & $\begin{array}{l}8 \\
(7.5)\end{array}$ & 0 & 0 & $\begin{array}{l}2 \\
(1.9)\end{array}$ & 3.9 & 1 \\
\hline $\begin{array}{l}\text { Accessibility to } \\
\text { credit facilities }\end{array}$ & $\begin{array}{l}6 \\
(5.7)\end{array}$ & $\begin{array}{l}10 \\
(9.4)\end{array}$ & $\begin{array}{l}30 \\
(28.3)\end{array}$ & $\begin{array}{l}60 \\
(56.6)\end{array}$ & 0 & 2.1 & 9 \\
\hline Culture & $\begin{array}{l}51 \\
(48.1)\end{array}$ & $\begin{array}{l}20 \\
(18.9)\end{array}$ & $\begin{array}{l}25 \\
(23.5)\end{array}$ & $\begin{array}{l}10 \\
(9.5)\end{array}$ & 0 & 3.0 & 6 \\
\hline Educational Status & $\begin{array}{l}26 \\
(24.5)\end{array}$ & $\begin{array}{l}20 \\
(18.9)\end{array}$ & $\begin{array}{l}30 \\
(28.3)\end{array}$ & $\begin{array}{l}25 \\
(23.5)\end{array}$ & $\begin{array}{l}5 \\
(4.8)\end{array}$ & 2.3 & 7 \\
\hline $\begin{array}{l}\text { Increase in prices } \\
\text { of food items }\end{array}$ & $\begin{array}{l}11 \\
(10.4)\end{array}$ & $\begin{array}{l}15 \\
(14.3)\end{array}$ & $\begin{array}{l}40 \\
(38.1)\end{array}$ & $\begin{array}{l}30 \\
(28.6)\end{array}$ & $\begin{array}{l}10 \\
(9.5)\end{array}$ & 1.9 & 10 \\
\hline $\begin{array}{l}\text { Type of farm tasks } \\
\text { performed }\end{array}$ & $\begin{array}{l}3 \\
(2.8)\end{array}$ & $\begin{array}{l}10 \\
(9.4)\end{array}$ & $\begin{array}{l}38 \\
(35.9)\end{array}$ & $\begin{array}{l}55 \\
(51.9)\end{array}$ & 0 & 1.6 & 11 \\
\hline Interest/ hobby & $\begin{array}{l}26 \\
(24.5)\end{array}$ & $\begin{array}{l}18 \\
(17)\end{array}$ & $\begin{array}{l}22 \\
(20.8)\end{array}$ & $\begin{array}{l}40 \\
(35.8)\end{array}$ & 0 & 2.2 & 8 \\
\hline Skills/ experience & $\begin{array}{l}66 \\
(62.3)\end{array}$ & $\begin{array}{l}35 \\
(33)\end{array}$ & $\begin{array}{l}3 \\
(2.8)\end{array}$ & $\begin{array}{l}2 \\
(1.9)\end{array}$ & 0 & 3.6 & 3 \\
\hline
\end{tabular}

Source: Researcher's own fieldwork, 2018

From Table 2, accessibility to fertile land $(\mathrm{x}=3.9)$ to produce watermelon is the most important determinant of rural farmers' diversification to 
watermelon production in the study area. This result is similar to that of Adojutelegan et al. (2015) who reported that improved soil fertility and income generation are the reasons for farmers' cultivation of watermelon in Ekiti State, Nigeria. Income generation (mean of 3.7) was ranked second motivating farmers' involvement in watermelon production. Income generated from the sales of harvested watermelon can be used to cater for other expenses such as purchase of other food items, household items, acquire assets, expand the farm and pay school fees among others. This result is in support of Ibeawuchi et al. (2015) that fruits and vegetables contribute to the income of both the rural and urban dwellers. Skills/experience is the third ranked determinant (mean of 3.6), where the technical knowledge accrued to these farmers in growing watermelon has encouraged them into the business. Unemployment (mean of 3.2) is the fourth ranked reason for farmers' involvement in watermelon production. Other reasons including nutritional benefits and culture were also important among others.

Table 3. Perception of impact of income from Watermelon on the Livelihood of the Producers (\% within parentheses).

\begin{tabular}{|c|c|c|c|c|c|c|c|}
\hline Impact & $\begin{array}{l}\text { Strongly } \\
\text { Agree }\end{array}$ & Agree & Disagree & $\begin{array}{l}\text { Strongly } \\
\text { disagree }\end{array}$ & Undecided & $\begin{array}{l}\text { Weighted } \\
\text { Mean } \\
\text { (X) }\end{array}$ & Rank \\
\hline $\begin{array}{l}\text { Assist in the } \\
\text { expenditure on } \\
\text { household items }\end{array}$ & $\begin{array}{l}87 \\
(82.1)\end{array}$ & $\begin{array}{l}13 \\
(12.3)\end{array}$ & $6(5.6)$ & 0 & 0 & 3.8 & 2 \\
\hline Acquire assets & $\begin{array}{l}70 \\
(66)\end{array}$ & $\begin{array}{l}15 \\
(14.2)\end{array}$ & $\begin{array}{l}15 \\
(14.2)\end{array}$ & $\begin{array}{l}5 \\
(4.7)\end{array}$ & $\begin{array}{l}1 \\
(0.9)\end{array}$ & 3.4 & 3 \\
\hline $\begin{array}{l}\text { Expenditure on } \\
\text { food items }\end{array}$ & $\begin{array}{l}90 \\
(84.9)\end{array}$ & $\begin{array}{l}16 \\
(15.1)\end{array}$ & 0 & 0 & 0 & 3.9 & 1 \\
\hline $\begin{array}{c}\text { Pay children' } \\
\text { school fees }\end{array}$ & $\begin{array}{l}30 \\
(28.3)\end{array}$ & $\begin{array}{l}5 \\
(4.7)\end{array}$ & $\begin{array}{l}50 \\
(47.1)\end{array}$ & $\begin{array}{l}15 \\
(14.2)\end{array}$ & $\begin{array}{l}6 \\
(5.6)\end{array}$ & 2.4 & 5 \\
\hline Savings/thrift & $\begin{array}{l}6 \\
(5.6)\end{array}$ & $\begin{array}{l}10 \\
(9.4)\end{array}$ & $\begin{array}{l}36 \\
(34)\end{array}$ & 0 & $\begin{array}{l}54 \\
(51)\end{array}$ & 1.2 & 9 \\
\hline $\begin{array}{r}\text { Loan/debt } \\
\text { servicing }\end{array}$ & $\begin{array}{l}2 \\
(1.9)\end{array}$ & $\begin{array}{l}5 \\
(4.7)\end{array}$ & $\begin{array}{l}45 \\
(42.4)\end{array}$ & $\begin{array}{l}54 \\
(51)\end{array}$ & 0 & 1.6 & 8 \\
\hline $\begin{array}{l}\text { Increase farm } \\
\text { size }\end{array}$ & $\begin{array}{l}2 \\
(1.9)\end{array}$ & $\begin{array}{l}8 \\
(7.5)\end{array}$ & $\begin{array}{l}70 \\
(66)\end{array}$ & $\begin{array}{l}26 \\
(24.6)\end{array}$ & 0 & 1.9 & 6 \\
\hline $\begin{array}{l}\text { Accessibility to } \\
\text { fresh } \\
\text { nutritious fruit }\end{array}$ & $\begin{array}{l}56 \\
(52.8)\end{array}$ & $\begin{array}{l}30 \\
(28.3)\end{array}$ & $\begin{array}{l}20 \\
(18.9)\end{array}$ & 0 & 0 & 3.3 & 4 \\
\hline $\begin{array}{l}\text { Purchase farm } \\
\text { input }\end{array}$ & $\begin{array}{l}25 \\
(23.6)\end{array}$ & $\begin{array}{l}10 \\
(9.4)\end{array}$ & $\begin{array}{l}25 \\
(23.6)\end{array}$ & $\begin{array}{l}16 \\
(15.1)\end{array}$ & $\begin{array}{l}30 \\
(28.3)\end{array}$ & 1.8 & 7 \\
\hline
\end{tabular}

Source: Researcher's own fieldwork, 2018

\subsection{Impact of watermelon on the livelihood of the producers}


In order to determine the perception of the impact of watermelon production on the livelihood of its producers, some variables were considered with the use of Likert rating scale as revealed in Table 3. Expenditure on food items (mean of 3.9) was ranked first as most important impact that sales of watermelon have on the growers. This means income realized from watermelon is being used to purchase food items for the growers' households majorly.

The second important impact that the income realized from the sales of watermelon has on farmers is that it assists in the area of expenditure on household items $(x=3.8)$. This indicates that income realized from the sales of watermelon is also used to purchase household items. The third important impact through income realized from sales of watermelon is to acquire assets with a mean value of 3.4 (such as radio, television, land, grinding machine, and bike among others) and accessibility to fresh nutritious food has a mean value of 3.3 .

Table 4. Respondents' ranking of challenges confronting watermelon production.

\begin{tabular}{|c|c|c|c|c|c|c|c|c|c|c|c|c|c|}
\hline \multirow{2}{*}{ Problems } & \multicolumn{13}{|c|}{ Respondents / Ranks ${ }^{a}$} \\
\hline & 1 & 2 & 3 & 4 & 5 & 6 & 7 & 8 & 9 & 10 & 11 & 12 & 13 \\
\hline $\begin{array}{l}\text { 1. Inadequate } \\
\text { capital/credit facilities }\end{array}$ & 50 & 42 & 13 & - & 1 & - & - & - & - & - & - & - & - \\
\hline $\begin{array}{l}\text { 2. Lack of access to } \\
\text { fertile land }\end{array}$ & 37 & 21 & 38 & - & - & 4 & 1 & 4 & 1 & - & - & - & - \\
\hline 3. Pest \& diseases & - & 1 & - & 4 & 7 & 18 & 26 & 16 & 13 & 9 & - & - & 12 \\
\hline 4. Lack of technology & - & - & - & 17 & 35 & 27 & - & 13 & 9 & - & - & 5 & - \\
\hline $\begin{array}{l}\text { 5. Lack of extension } \\
\text { services }\end{array}$ & - & - & - & 4 & - & 1 & 10 & 4 & 4 & 9 & - & 43 & 31 \\
\hline 6. Marketing problem & - & - & 9 & 15 & 12 & 13 & 13 & 26 & 6 & - & - & 4 & 8 \\
\hline $\begin{array}{l}\text { 7. Poor road condition/ } \\
\text { inadequate } \\
\text { transportation }\end{array}$ & 4 & - & 40 & 39 & 10 & 9 & 4 & - & - & - & - & - & - \\
\hline $\begin{array}{l}\text { 8. lack of farm input/seed } \\
\text { procurement }\end{array}$ & - & - & - & - & 8 & - & - & - & 12 & 39 & 29 & 9 & 9 \\
\hline 9. Poor seasonal rainfall & - & - & - & - & 9 & - & - & - & 4 & 19 & 32 & 19 & 23 \\
\hline 10. Lack of education & - & - & - & - & - & - & - & 1 & 27 & 13 & 36 & 12 & 17 \\
\hline 11. Middlemen problem & - & - & - & - & 13 & 18 & 30 & 26 & 5 & 5 & 9 & - & - \\
\hline $\begin{array}{l}\text { 12. Perishability/lack of } \\
\text { storage facilities }\end{array}$ & 15 & 42 & 6 & 14 & 9 & 16 & 4 & - & - & - & - & - & - \\
\hline 13. Pilfering & - & - & - & 13 & 2 & - & 18 & 16 & 25 & 12 & - & 14 & 6 \\
\hline
\end{tabular}

Source: Researcher's own fieldwork, 2018

${ }^{a}$ Ranks are given from 1 to 13 ; Rank 1 is considered the most severe constraint to watermelon farmers while rank 13 is the least severe constraint. 


\subsection{Constraints faced by farmers in Watermelon Production}

When asked about the challenges faced by the watermelon farmers in the study area, (Table 4) a total of 92 sampled farmers ranked inadequate capital/credit facilities for the production of watermelon as the first or the second most pressing problem constraining their increased production. This agrees with the findings of Adeoye et al. (2011) and Ajewole (2015) that inadequate credit is a major constraint to watermelon production in Nigeria. This has a big influence on the increase in production since capital is needed to expand the farm and increase production. A total of 58 sampled farmers ranked lack of access to adequate fertile land as first or second most pressing problem constraining their production in the study area. The aforementioned could be linked with the land tenure system available in the study area since most of these watermelon farmers are outsiders; they must rent the land occupied. The fear that they can be chased away at any time by the owner of the land has really constrained their expansion. Fifty-seven sampled farmers ranked perishability or lack of storage facilities as the first and second most pressing problems. It corroborates the findings of Ekerete and Asa (2014) that the most severe constraints to watermelon marketing in Uyo Metropolis, Akwa Ibom State, Nigeria include losses resulting from fruits spoilage, lack of preservation facilities, high cost of transportation, and lack of credit facilities.

Furthermore, 44 sampled farmers ranked poor road condition/inadequate transportation as the first, second or third most pressing problems. By nature, watermelon fruits are heavy, and if the roads leading to where they are being produced are bad, transporting them to the destination will be a very serious problem. According to the sampled farmers, they said the roads that lead to their different farms are very bad and as a result, it has affected the cost of transportation. They also reported that they do not have access to extension services at all in the area.

Other problems confronting watermelon farmers in the study area but were ranked differently include lack of technical knowhow, lack of extension services, pests and diseases, pilfering, poor seasonal rainfall, marketing problems, middlemen problem, lack of farm input and lack of education. This corroborates the report by Adojutelegan et al. (2015) that lack of capital, poor markets, perishable nature of watermelon and lack of technology for large scale production were the serious constraints faced by farmers during the cause of production of watermelon.

\section{Conclusions}

From the study, it was discovered that most farmers diversify into watermelon production in the study area because of the type of soil found in the area 
which is loamy, and the income being realized from their sales. It can therefore be concluded that watermelon production has really contributed significantly to the income, health and livelihood of the people involved in it. Hence, the practice of horticulture should be encouraged more in rural areas of Nigeria for sustainable rural development. What happened in Ifelodun Local Government, Kwara State could be a minor thing if farmers are given adequate attention, as this could be replicated in other parts of the country for sustainable agricultural development. Proper institutional framework towards the development and growth of watermelon should therefore be put forward by policy makers. Farmers should equally be encouraged more in the production of watermelon by providing them with necessary farm input to realize increased production.

\section{Acknowledgements}

Comments from two anonymous RJS reviewers on the initial draft of the submitted manuscript are acknowledged.

\section{References}

Adekunle AA, Fatunbi AO, Adisa S, Adeyemi OA. 2007. Growing watermelon commercially in Nigeria: An illustrated guide. USAID ICS-NIGERIA and IITA. Retrieved October 5, 2012,from http://www.fao.org/sd/erp/toolkit/BOOKS/watermelon_illust_guidebook.pdf

Adeoye IB, Olajide-Taiwo FB, Adebisi-Adelani O, Usman, JM. Badmus MA2011. Economic analysis of watermelon-based production system in Oyo state, Nigeria. ARPN Journal of Agricultural and Biological Science 6(7): 53-59.

Adojutelegan OT, Adereti FO, Makanju TS, Olorunfemi OD 2015. Analysis of Factors Affecting Watermelon in Ekiti State, Nigeria. Science, Technology and Arts Research Journal 4(2):324-329.

Agricultural Marketing Resource Center 2018. Watermelon. USDA Office. Washington D.C. https://www.agmrc.org.

Ajewole OC 2015. Income and Factor Analysis of Watermelon Production in Ekiti State, Nigeria. Journal of Economics and Sustainable Development 6(2):67-71.

Baxley R. 2018. Farming 2018: Watermelon no longer just a summer fruit due to its health benefits. The Times and Democrat. 1010 Broughton Street Orangeburg, SC. https://www.agmrc.org>vegetables>watermelon

Dan-Azumi JJ. 2011. Agricultural Sustainability of Smallholder Floodplain Agricultural Systems: A Case Study of Fadama Areas in North-Central Nigeria. A Ph.D. Thesis Submitted to Development Planning Unit/Bartlett Faculty of the Built Environment, University College, London. http://discovery.ucl.ac.uk/id/eprint/138073.

Dhaliwal MS. 2017. Cucurbits. Handbook of Vegetable Crops $3^{\text {rd }}$ Edition. Published by Kalyani Publishers. https://wwwresearchgate/publication/313098886.

Dauda SN, Ajayi FA, Ndor E, 2008. Growth and Yield of Watermelon as Affected by Poultry Manure Application. Electronic Journal of Environment, Agriculture and Food chemistry 7 (7):3108-3114.

Egbe EJ 2014. Rural Community and Development in Nigeria. An Assessment. OSR Journal of Humanities and Social Science (IOSR-JHSS)19 (3):104-112. 
Ebiwoei KP 2013. Marketing margin and determinants of net return of watermelon marketing in Yenagoa Metropolis of Bayelsa State, Nigeria. Journal of Experimental Biology and Agricultural Science 1 (4): 241-247.

Ekerete BI, Asa UA 2014. Constraints to Watermelon Marketing in Uyo Metropolis of Akwa Ibom State, Nigeria. Journal of Agriculture and Environmental Sciences 3 (4): 63-69. doi: 10.15640/jaes.v3n4a5 URL: http://dx.doi.org/10.15640/jaes.v3n4a5.

Enukainure OL, Oke OV, Daramola AO, Adenekan SO, Umanhonlem EE. 2010. Improvement of biochemical properties of watermelon rinds subjected to $S$. cerevisiae solid media fermentation. Pakistan Journal of Nutrition 9(8):806-809. doi:10.3923/pjn.2010.806.809.

FAO 2003. World Agriculture: towards 2015/2030. Summary report, Rome. Eds Bruinsma, Journal. Earthscan Publications Limited. https://www.fao.org.

Gyulai G, Toth Z, Bittsanszky A. 2011. Medieval Citrullus DNAs-unlocking domestication events (13th and 15th cent). In: Plant Archaeogenetics. Edited by G Gyulai. Chapter 7. Nova Science Publisher Inc., New York, USA.

Ibeawuchi II, Okoli NA, Alagba RA, Ofor MO, Emma-Okafor LC, Peter-Onoh CA, Obiefuna JC. 2015. Fruit and Vegetable Crop Production in Nigeria: The Gains, Challenges and The Way Forward. Journal of Biology, Agriculture and Healthcare 5(2): 194-209.

Inuwa HM, Aina VO, Gabi B, Aimola I, Thompson V. 2011. Determination of differences in nutrient composition of Citrullus vulgaries (watermelon) fruits after plucking. British Journal of Dairy Science 2(2):27-30.

Mohammed BT. 2008. Economics Analysis of Melon (Citritillus Lanatus) Production in Kwara State. Proceeding of $2^{\text {nd }}$ Annual Conference Agric Society of Nigeria (ASN) held on 19th$23^{\text {rd }}$ October at Abakaliki. 57-58pp.

Mohammed BT. 2011. Socio-economic Analysis of Melon Production in Ifelodun Local Government Area, Kwara State, Nigeria. Journal of Development and Agricultural Economics 3(8):362-367.

Namdari M, Mohammedi A, Mobtaker HG. 2011. Assessment of energy requirements and sensitivity analysis of inputs for watermelon production in Iran. International Journal of Plant, Animal and Environmental Sciences 1(1).

National Population Commission (NPC) 2006. Population Census Report. National Population Commission Census 2006. Nigeria.

National Research Council 2008. Lost Crops of Africa. Volume III: Fruits, Washington, D.C. The National Academies Press.

Oguntola S. 2006. Watermelon: Hidden gem yet to be discovered. Nigerian Tribune Thursday 13th July 2006. In A. Ya'u, B. A. Mahmoud, \& H. Kubura (ed.), Profitability of Water Melon Production and Marketing in Kirfi Local Government Area of Bauchi State, Nigeria. Proceedings of the 25th Farm Management Association of Nigeria (FAMAN) Conference, 5th - 8th September 2011, Akure, Nigeria.

Peet M. 1995. Sustainable Practice for Vegetable Production in the South, NCSU.

Schippers RR. 2000. African Indigenous Vegetable, An Overview of the Cultivated species, N.R/ACO, EU. Chatthan, UK. 56-60pp

Ufoegbune GC, Fadipe OA, Bello NJ, Eruola, AO, Makinde AA. 2014. Growth and Development of Watermelon in Response to Seasonal Variation of Rainfall. Journal of Climatology \& Weather Forecasting 2:117. doi:10.4172/2332-2594.1000117.

Yusuf SFG, Lategan FS, Ayinde IA 2013 Profitability and Adoption of Watermelon Technologies by Farmers in Moro Local Government of Kwara State, Nigeria. Journal of Agricultural Science 5(5):91-99. doi:10.5539/jas.v5n5p91.

Zafour 2007. Report on Production and Marketing System of Watermelon in Selected Areas of Patuakhali District. Department of Agricultural Economics and Rural Sociology, Faculty of Business Administration and Management, Patuakhali Science and Technology University, Bangladesh. 